\title{
FAKTOR NASABAH MEMILIH BMT MANDIRI SEJAHTERA GRESIK'1)
}

\author{
Syukron Makmun \\ Mahasiswa Program Studi S1 Ekonomi Islam-Fakultas Ekonomi dan Bisnis-Univeritas Airlangga \\ Email : syukronm93@gmail.com \\ Ririn Tri Ratnasari \\ Departemen Ekonomi Syariah- Fakultas Ekonomi dan Bisnis-Univeritas Airlangga \\ Email: ri.ratnasari@gmail.com
}

\begin{abstract}
:
This research is set to determine the factors that influence the customer in choosing BMT Mandiri Sejahtera Gresik which has a customer base of more than twenty thousand. This study uses a quantitative method with exploratory factor analysis. Characteristics of the population in this study is the customer BMT Mandiri Sejahtera. The number of samples at the time of the interview written test prelemenery test as 9 respondents, and to main test as many as 85 respondents. Sampling technique used was purposive sampling where the sample is taken from the customer BMT Mandiri Sejahtera Karangcangkring Central Office. Based on the results of the study indicate that there are six factors that affect the customer's decision choosing BMT Mandiri Sejahtera. Six such factors as a result of reduction of the processing of factor analysis. These six factors are named by a factor of revenue sharing, religiosity factors, factors of marketing strategies, factors saving gift, factor customer service, and the administrative cost factor.
\end{abstract}

Keywords: Baitul Maal wa Tamwil, Consumer BMT, Analysis Factor, choosing BMT

\section{PENDAHULUAN}

Seiring dengan berkembangnya Ekonomi Islam, berkembang pula Lembaga keuangan yang syar'i, Lembaga keuangan Islam terdiri dari perbankan (yang terdiri dari bank umum syariah dan bank perkreditan syariah), dan lembaga-lembaga keuangan nonbank yang salah satunya bersifat mikro yaitu Baitul Maal wa Tamwil (Sudarsono, 2008:8). Baitul Maal wat-Tamwil (BMT) beroperasi berdasarkan prinsip syariah yang memiliki fungsi untuk memberdayakan ekonomi umat, dan memiliki fungsi sosial. Dewasa ini, dengan semakin berttumbuh pesatnya BMT, masyarakat mulai melirik untuk menanamkan dana maupun menggunakan jasa BMT.

Terkait dengan faktor yang dapat mempengaruhi konsumen menggunakan jasa, Kotler (2001:191) menjelaskan antara lain faktor kebudayaan, sosial, pribadi dan psikologi. Faktor kebudayaan dipengaruhi oleh kelas budaya, subbudaya, dan kelas sosial. Faktor sosial dipengaruhi oleh kelompok referensi, keluarga, peran dan status. Faktor pribadi dipengaruhi oleh usia dan tahap siklus hidup, pekerjaan, keadaan ekonomi, gaya hidup, serta kepribadian konsep diri. Sedangkan faktor psikologi dipengaruhi oleh motivasi, persepsi pembelajaran, keyakinan dan sikap.

\section{LANDASAN TEORI}

1) Jurnal ini merupakan bagian dari skripsi dari Syukron Makmun, NIM : 041114008 , yang diuji pada 10 Agustus 2015 
Dalam mengambil suatu keputusan konsumen terdapat faktor yang mempengaruhi (Ratnasari, 2013), antara lain :

1. Faktor Keimanan

Di dalam Islam, perilaku konsumen berasal dari akhlak yang berarti budi pekerti, peringai, tingkah laku, dan tabiat. Akhlak merupakan suatu kondisi atau sifat yang telah meresap dalam jiwa dan menjadi kepribadian hingga timbul berbagai macam perbuatan secara spontan, tanpa dibuat-buat dan tanpa memerlukan pemikiran. Perilaku konsumen Islam harus mencerminkan hubungan dirinya Allah SWT. Perilaku konsumen muslim merupakan perilaku yang dilandasi iman dan ketakwaan pada Allah SWT dimana seorang muslim memanfaatkan harta yang dihasilkan untuk kebutuhan individu, keluarga, dan dibelanjakan di jalan Allah SWT (fi sbilillah).

2. Faktor Individual Konsumen (Individual Consumer)

Merek yang dipilih konsumen dipengaruhi oleh kebutuhan, persepsi terhadap karakteristik merek, sikap terhadap merek, demografi, gaya hidup, dan kepribadian konsumen.

3. Faktor Strategi Pemasaran

Faktor strategi pemasaran merupakan variabel-variabel yang dapat dikendalikan oleh pemasar dalam upaya untuk menginformasikan dan mempengaruhi konsumen. Variabel tersebut meliputi produk, harga, promosi, dan saliran distribusi yang nantinya menjadi bahan pertimbangan bagi konsumen dalam proses pengambilan keputusan.

4. Faktor Pengaruh Lingkungan (Environment Influences)

Lingkungan pembelian konsumen dipengaruhioleh kebudayaan, termasuk norma dan nilai-nilai dari masyarakat (the norms and value of society) sub budaya, kelompok tatap muka, yaitu teman, anggota keluarga, kelompok referensi (friends, family member, and references group) dan faktor situasi (keadaan untuk apa produk atau jasa dibeli). Merupakan sumber informasi yang penting karena dapat mempengaruhi perilaku konsumen, karena kelompok ini berperan bagi individu didalam membentuk kepercayaan, sikap dan perilakunya.

\section{METODE PENELITIAN}

Penelitian ini menggunakan pendekatan kuantitatif eksploratori Dalam penelitian yang menggunakan analisis faktor, tidak diidentifikasikan variabel bebas maupun variabel terikat. Pada penelitian ini dirumuskan 17 indikator yang akan direduksi menjadi faktor atau variabel.

Definisi operasional yang dianalisis adalah sebagai berikut:

1. Menabung di BMT Mandiri Sejahtera mendapatkan ketenangan hati, karena terhindar dari adanya transaksi riba $\left(X_{1}\right)$ adalah visi bmt mandiri sejahtera sebagai lembaga keuangan mikro yang bebas dari riba. 
2. BMT Mandiri Sejahtera merupakan BMT yang bernuansa Islami (terdapat tulisan ayat Al-Quran di dinding/ terdengar suara ayat Al-Quran/ ucapan salam dari karyawan) ( $\left.X_{2}\right)$ adalah suasana BMT Mandiri Sejahtera yang bernuansa Islami dengan adanya tulisan ayat AlQur'an di dinding, terdengar suara ayat Al-Qur'an, ucapan salam dari karyawan kepada nasabah.

3. Lokasi bmt mandiri sejahtera dekat dari rumah atau tempat bekerja $\left(X_{3}\right)$ adalah jarak bmt mandiri sejahtera dari rumah maupun tempat kerja.

4. Memperoleh informasi mengenai BMT Mandiri Sejahtera dari orang terdekat $\left(X_{4}\right)$ adalah keterangan orang terdekat yang memberi informasi dan gambaran tentang BMT Mandiri Sejahtera.

5. Proses pelayanan pada BMT Mandiri Sejahtera cepat (ketika menarik vang/ menabung/ pembukaan rekening online) ( $\left.X_{5}\right)$ adalah ketanggapan pelayanan yang diberikan BMT Mandiri Sejahtera.

6. Termotivasi menjadi nasabah di BMT Mandiri Sejahtera karena tiap tahun terdapat doorprize atau adanya pembagian hadiah ( $\left.X_{6}\right)$ adalah adanya motivasi nasabah dikarenakan pemberian hadiah oleh BMT Mandiri Sejahtera.

7. Tidak terdapat bmt ataupun bank yang terdekat selain BMT Mandiri Sejahtera $\left(X_{7}\right)$ adalah tidak tersedia bmt maupun bank lain di sekitar kawasan selain BMT Mandiri Sejahtera.

8. Proses pendaftaran menjadi anggota BMT Mandiri Sejahtera tidak rumit $\left(\mathrm{X}_{8}\right)$ adalah persyaratan pendaftaran pada BMT Mandiri Sejahtera tidak rumit.

9. Sudah lama menjadi nasabah BMT Mandiri Sejahtera ( $X_{9}$ ) adalah berapa lama nasabah telah menjadi anggota BMT Mandiri Sejahtera.

10. BMT Mandiri Sejahtera menyeleksi calon nasabah sebelum mendaftar $\left(X_{10}\right)$ adalah seleksi yang dilakukan BMT Mandiri Sejahtera sebelum menjadi anggota.

11. Karyawan BMT Mandiri Sejahtera berpengalaman dalam menangani masalah nasabah $\left(X_{11}\right)$ adalah proses penanganan oleh karyawan ketika menangani masalah nasabah.

12. Biaya menabung di BMT Mandiri Sejahtera murah dan terjangkau oleh semua kalangan $\left(X_{12}\right)$ adalah biaya yang dikeluarkan konsumen untuk menabung di BMT Mandiri Sejahtera.

13. Bagi hasil yang ditawarkan BMT Mandiri Sejahtera tinggi $\left(X_{13}\right)$ adalah nisbah bagi hasil yang diberikan kepada nasabah tinggi.

14. BMT Mandiri Sejahtera memberikan dana sosial/ dana kebajikan (seperti santunan kepada anak yatim/ bantuan kepada murid yang tidak bisa membayar sekolah) ( $\left.X_{14}\right)$ adalah penyaluran dana kebaikan oleh BMT Mandiri Sejahtera. 
15. Mengetahui adanya BMT Mandiri Sejahtera karena dulunya pernah didatangi oleh karyawan atau manajer untuk menawarkan jasa bmt $\left(X_{15}\right)$ adalah cara pemasaran BMT Mandiri Sejahtera yang jemput bola mengunjungi konsumen.

16. BMT Mandiri Sejahtera menjadi referensi untuk menabung ataupun meminjam pembiayaan bagi keluarga maupun rekan kerja (X16) adalah bmt sebagai referensi bagi keluarga maupun rekan kerja.

17. BMT Mandiri Sejahtera memiliki citra perusahaan yang baik di mata nasabah $\left(\mathrm{X}_{17}\right)$ adalah pandangan baik dari suatu pihak kepada BMT Mandiri Sejahtera.

Pengukuran pada penelitian ini dapat diketahui dan pertanyaan kuesioner yang diukur dengan menggunakan skala Likert. Jumlah sampel pada saat preliminary test dengan melakukan wawancara tertulis sebanyak 9-12 responden yang diwakili oleh nasabah BMT Mandiri Sejahtera, dan untuk main test sebanyak 85 responden

Teknik pengambilan sampel yang digunakan adalah purposive sampling , peneliti mendapatkan responden dengan cara menyebar kuisioner pada nasabah BMT Mandiri Sejahtera Kantor Pusat Karangcangkring.

Salah satu teknik yang sering digunakan dalam analisis multivariate adalah analisis faktor. Analisis faktor digunakan untuk mrnganalisis faktor-faktor yang menjadi pertimbangan nasabah memilih BMT Mandiri Sejahtera. Langkahlangkah yang dilakukan dalam analisis faktor yaitu:

1. Merumuskan masalah

Merumuskan idnikator-indikator yang akan dipilih untuk dilakukan analisis faktor

2. Mmebuat Matriks Korelasi, yaitu dengan pengujian

a. Barlett's test of sphercity (Uji Barlett's sphercity) yang digunakan untuk mengkaji interpendensi antara butirbutir yang menjadi indikator jumlah variabel atau faktor.

b. Kaiser-Meyer-Olkin (KMO) measure of sampling adequancy, adalah angka indeks untuk membandingkan antara besarnya koefisien korelasi observasi dengan besamya koefisien korelasi parsial

c. Correlation matrix, yaitu matrik korelasi yang merupakan hasil korelasi antar butir yang menunjukkan koefisien korelasi (r) antara butir satu dengan butir yang lainnya

3. Menentukan Jumlah Faktor Penentuan jumlah faktor didasarkan eigenvalue setiap faktor yang muncul.

4. Rotasi faktor 
Dilakukan untuk mempermudah interpretasi.

5. Interpretasi Faktor

Dilakukan dengan cara mengelompokkan indicator yang mempunyai faktor loading yang tinggi ke dalam faktor tersebut.

\section{HASIL DAN PEMBAHASAN}

\section{Karakteristik Responden}

Pada Tabel 1. Menjelaskan responden yang berjenis kelamin pria sebanyak 49 orang (58 \% dari total responden), sedangkan responden berjenis kelarnin wanita sebanyak 36 orang $(42 \%$ dari total responden). Responden usia kurang dari 20 tahun sebanyak 2 orang (2\% dari total responden), usia 21 - 30 tahun sebanyak 8 orang (10\% dari total responden), usia 31 40 tahun sebanyak 21 orang ( $25 \%$ daritotal responden), usia 41 - 50 tahun sebanyak 18 orang ( $21 \%$ dari total responden), dan yangberusia $<50$ tahun sebanyak 36 orang (42\% dan total responden), Responden pendidikan terakhir asal SD sebanyak 31 orang (36\% dari total responden), SMP sebanyak 31 orang $136 \%$ dari total responden), SMA sebanyak 18 orang (22\% dari total responden), S1 sebanyak 1 orang (1\% dari total responden). Pekerjaan responden sebagai Pedagang sebanyak 31 orang $136 \%$ dari total responden), Wiraswasta sebanyak 13 orang (15\% dari total responden), Petani sebanyak 22 orang $(26 \%$ dari total responden) Karyawan sebanyak 6 orang (7\% dari total responden), Ibu Rumah
Tangga sebanyak 11 orang (13\% dari total responden), dan Lain-lain sebanyak 2 orang $13 \%$ dari total responden. responden berasal dari Gresik sebanyak 74 orang (87\% dari total responden), Responden berasal dari Lamongan sebanyak 10 orang (12\% dari total responden), dan dari luar Gresik dan Lamongan sebanyak 1 orang $1 \%$ dari total responden)

\section{Analisis Faktor}

Adapun langkah-langkah yang harus dilakukan dalam pelaksanaan anailisis faktor menurul Malhotra adalab sebagai berikut:

1. Matriks Korelasi

Anatisis faktor yang pertama

dilakukan

adalah menilai indikator mana saja yang dianggap layak untuk dimasukkan ke dalam analisis selanjutnya. Syarat kecukupan atau tidak untuk analisis faktor dengan rnenggunakan uji Keiser Meyer Olkin (KMO) dan Bartlett's Test. Hasil pengujian awal rnemperlihatkan bahwa besarnya nilai Keiser Meyer Olkin Measure of Sampling Adequacy (KMO-MSA) bernilai di atas 0,5 dengan Bartlett's Test memiliki signifikasi 0,000 . Hal ini berarti bahwa seluruh indikator memenuhi syarat MSA, sehingga layak untuk dilakukan analisis selanjutnya. Simarnora (2004) menjelaskan bahwa, kesimpulan tentang !ayak tidaknya 


\begin{abstract}
analisis faktor dilakukan, baru sah secara statistik dengan menggunakan uji KMO-MSA. KMO uji yang nilainya berkisar antara 0 sampal 1 ini mempertanyakan kelayakan (appropriatness) analisis faktor. Apabila indeks tinggi (berkisar antara 0,5 sampai 1,0), analisis faktor layak dilakukan. Sebaliknya, kalau nilai KMO di bawah 0,5 analisis faktor tidak layak dilakukan.

Dalam Perhitungan Tabel AntiImage Matrix masih didapatkan indikator yang memiliki nilai MSA dibawah 0,5. Oleh karena itu maka indicator dengan nilai dibawah 0,5 dikeluarkan yaitu $X_{5}$ proses pelayanan cepat $X_{7}$ tidak terdapat bmt lain dikeluarkan dari analisis
\end{abstract}

Tabel 1.

Karakteristik Responden

\begin{tabular}{lll}
\hline Karakteristik & Jumlah & $\begin{array}{l}\text { Perse } \\
\text { Responden }\end{array}$ \\
\hline
\end{tabular}

Jenis Kelamin

Perempuan

$36 \quad 42$

Laki-laki

$49 \quad 58$

Total

Usia

$>20$ Tahun

21-30 Tahun

31-40 Tahun

41-50 Tahun

\section{5}

100

$2 \quad 2$

$8 \quad 10$

$21 \quad 25$

$18 \quad 21$

$<50$ Tahun 36

Total

85 42

\section{Pendidikan}

SD

$31 \quad 36$

SMP

$31 \quad 36$

SMA

$18 \quad 22$

S1

Lain-lain

$1 \quad 1$

Total

45

$85 \quad 100$

Pekerjaan

$\begin{array}{lll}\text { Pedagang } & 31 & 36 \\ \text { Wiraswasta } & 13 & 15 \\ \text { Petani } & 22 & 26 \\ \text { Karyawan } & 6 & 7 \\ \text { Ibu Rumah Tangga } & 11 & 13 \\ \text { Lain-lain } & 2 & 3 \\ \text { Total } & 85 & 100\end{array}$

\section{Asal Daerah}

$\begin{array}{lll}\text { Gresik } & 74 \quad 87\end{array}$

$\begin{array}{lll}\text { Lamongan } & 10 \quad 12\end{array}$

Luar Lamongan dan 1

$\begin{array}{lll}\text { Gresik } & 85 & 100\end{array}$

Total

Sumber; Hasil Penelitian, 2015 (diolah)

Tabel 2.

Anti Image Matriks

\begin{tabular}{lc}
\hline Indikator & Nilai Korelasi \\
\hline X1 & 0,689 \\
X2 & 0,577 \\
X3 & 0,613 \\
X4 & 0,665 \\
X6 & 0,731 \\
X8 & 0,658 \\
X9 & 0,723 \\
X10 & 0,705 \\
X11 & 0,723 \\
X12 & 0,503 \\
X13 & 0,685 \\
X14 & 0,643
\end{tabular}


$\mathrm{X} 15$ 0,632

$\times 16$

$\times 17$

0,650

Sumber; Hasil Penelitian, 2015 (diolah)

Didapatkan hasil terdapat 15 indikator yang nilai MSA diatas 0,5 dan dapat dianalisis lebih lanjut. Selanjutnya Pada penentuan jumlah faktor merupakan langkah inti dalam analisis faktor, yaitu mengekstraksi sekumpulan indikatore yang ada, sehingga terbentuk satu atau lebih faktor. Metode yang digunakan dalam proses ini yaitu analisis komponen utarna (principal component analysis). Setelah proses ekstraksi dilakukan, dipero leh ni lai comm unalities. Communalities adalah jumlah keragaman dan suatu indikator mula-mula yang bisa dijelaskan oleh faktor yang terbentuk, sernakin tinggi nilai communality sebuah indikator berarti semakin erat hubungannya dengan faktor yang terbentuk (Dwipurwani dkk, 2009). Tabel 3 menunjukkan nilai communality dari 15 vaniabel yang dianalisis.

Hasil pada Tabel 3 menunjukkan nilai korelasi tertinggi pada indikator ke 1 dengan nilai 0,809. Ini menunjukkan nilai korelasi indikator pertama berkorelasi erat dengan faktor yang akan terbentuk. Sedangkan nilai yang paling rendah 0,542 pada indikator keenam yang berarti indikator tersebut berkorelasi paling rendah dengan faktor yang akan terbentuk
Tabel 3.

Communalities

\begin{tabular}{|l|r|}
\hline & Extraction \\
\hline $\mathrm{X} 1$ & 0,809 \\
\hline $\mathrm{X} 2$ & 0,764 \\
\hline $\mathrm{X} 3$ & 0,615 \\
\hline $\mathrm{X} 4$ & 0,597 \\
\hline $\mathrm{X} 6$ & 0,542 \\
\hline $\mathrm{X} 8$ & 0,580 \\
\hline $\mathrm{X} 9$ & 0,680 \\
\hline $\mathrm{X} 10$ & 0,576 \\
\hline $\mathrm{X} 11$ & 0,585 \\
\hline $\mathrm{X} 12$ & 0,717 \\
\hline $\mathrm{X} 13$ & 0,662 \\
\hline $\mathrm{X} 14$ & 0,544 \\
\hline $\mathrm{X} 15$ & 0,771 \\
\hline $\mathrm{X} 16$ & 0,606 \\
\hline $\mathrm{X} 17$ & 0,789 \\
\hline
\end{tabular}

Sumber; Hasil Penelitian, 2015 (diolah)

Pada pembentukan faktor ini terbentuk 6 faktor yang mempengaruhi nasabah memilih BMT Mandiri Sejahtera. Pembentukan faktor-faktor ini terdapat pada Tabel 4. Pada table terlihat enam faktor yang terbentuk memiliki nilai eigenvalue diatas 1.

Tabel 4.

Eigenvalues

Component Total Cumulative \%

$\begin{array}{lll}1 & 3,117 & 20,779 \\ 2 & 1,995 & 34,083 \\ 3 & 1,575 & 44,581 \\ 4 & 1,080 & 51,783 \\ 5 & 1,037 & 58,696\end{array}$


6

1,032

65,575

Sumber; Hasil Penelitian, 2015 (diolah)

\section{Rotasi Faktor}

Analisis selanjutnya adalah rotasi faktor, yang mana rotasi faktor ini dilakukan dengan tujuan menyederhanakan struktur dengan mentransformasi faktor untuk mendapatkan faktor baru yang lebih mudah untuk diinterpretasikan. Interpretasi yang dilakukan berdasarkan nilai loading fàktor yang terbentuk. Pada Tabel 5 menunjukan hasil loading faktor dan rotasi faktor. Nilai loading faktor didapatkan dan component matrix. Pada penelitian inii menggunakan rotasi dengan metode varimax, yang bertujuan untuk memperbesar nilai loading fáktor yang dulunya memang sudah besar dan memperkecil nilai loading fàktor yang dulunya memang sudah kecil, sehingga diperoleh distribusi loading fakror yang lebih jelas dan nyata.

Tabel 5.

Hasil Rotasi Faktor

\begin{tabular}{|l|lr|l|l|}
\hline No & Indikator & $\begin{array}{l}\text { Loading } \\
\text { Faktor }\end{array}$ & Faktor \\
\hline 1 & $\begin{array}{l}\text { Lokasi } \\
\text { (X3), }\end{array}$ & Sudah & 0,605 & Bagi Hasil \\
& lama & (X9), & 0,658 & \\
& Bagi & Hasil & 0,552 & \\
& (X13), & & \\
& Referensi & & \\
& (X16 & & \\
\hline
\end{tabular}

\begin{tabular}{|c|c|c|c|}
\hline 2 & $\begin{array}{l}\text { Terbebas } \\
\text { Riba (X1), } \\
\text { Nuansa } \\
\text { Islami (X2), } \\
\text { Mudah } \\
\text { daftar (X8) }\end{array}$ & $\begin{array}{l}0,880 \\
0,626 \\
0,654\end{array}$ & Religiusitas \\
\hline 3 & $\begin{array}{l}\text { Karyawan } \\
\text { pengalaman } \\
(X 11) \text {, Citra } \\
\text { Perusahaan } \\
\text { (X17) }\end{array}$ & $\begin{array}{l}0,604 \\
0,837\end{array}$ & $\begin{array}{l}\text { Citra } \\
\text { Perusahaan }\end{array}$ \\
\hline 4 & $\begin{array}{l}\text { Ada Hadiah } \\
\text { (X6), Seleksi } \\
\text { Nasabah } \\
\text { (X10) }\end{array}$ & $\begin{array}{l}0,706 \\
0,744\end{array}$ & $\begin{array}{l}\text { Hadiah } \\
\text { Menabung }\end{array}$ \\
\hline 5 & $\begin{array}{l}\text { Dulu } \\
\text { didatangi } \\
\text { staff (X15) }\end{array}$ & 0,829 & $\begin{array}{l}\text { Strategi } \\
\text { Pemasaran }\end{array}$ \\
\hline 6 & $\begin{array}{l}\text { Biaya } \\
\text { terjangkau } \\
(x 12)\end{array}$ & 0,828 & $\begin{array}{l}\text { Biaya } \\
\text { Administrasi }\end{array}$ \\
\hline
\end{tabular}

Sumber; Hasil Penelitian, 2015 (diolah)

Dari 15 indikator yang ada, terdapat dua indikator yang tidak memenuhi syarat. Dua indicator tersebut adalah Mendapat informasi dari orang terdekat (X4), BMT memberikan dana social (X14). 
Tabel 6.

Uji Validitas dan Reliabilitas

\begin{tabular}{|c|c|c|c|}
\hline Faktor & $\begin{array}{c}\text { Correct } \\
\text { ed Item } \\
\text { Total } \\
\text { Correlati } \\
\text { on }\end{array}$ & $\begin{array}{l}\text { Alpha } \\
\text { Cronba } \\
\text { ch }\end{array}$ & $\begin{array}{c}\text { Keteran } \\
\text { gan }\end{array}$ \\
\hline \multirow{4}{*}{$\begin{array}{l}\text { 1. Bagi } \\
\text { Hasil }\end{array}$} & 0,718 & \multirow[t]{4}{*}{0,813} & \multirow[t]{4}{*}{ Reliabel } \\
\hline & 0,426 & & \\
\hline & 0,437 & & \\
\hline & 0,448 & & \\
\hline \multirow{3}{*}{$\begin{array}{l}2 . \\
\text { Religiusit } \\
\text { as }\end{array}$} & 0,523 & \multirow[t]{3}{*}{0,709} & \multirow[t]{3}{*}{ Reliabel } \\
\hline & 0,411 & & \\
\hline & 0,784 & & \\
\hline \multirow{2}{*}{$\begin{array}{l}\text { 3. Citra } \\
\text { Perusah } \\
\text { aan }\end{array}$} & 0,410 & \multirow[t]{2}{*}{0,781} & \multirow[t]{2}{*}{ Reliabel } \\
\hline & 0,410 & & \\
\hline \multirow{2}{*}{$\begin{array}{l}4 . \\
\text { Hadiah } \\
\text { Menabu } \\
\text { ng }\end{array}$} & 0,574 & \multirow[t]{2}{*}{0,629} & \multirow[t]{2}{*}{ Reliabel } \\
\hline & 0,574 & & \\
\hline
\end{tabular}

Sumber; Hasil Penelitian, 2015 (diolah)

Uji reliabilitas dilihat dari nilai Cronbach Alpha lebih dari 0,6. Berdasar pada indikator yang telah terbentuk setelah dilakukannya exploratory faktor analysis, dinyatakan bahwa semua faktor reliabel,sehingga faktor yang terbentuk dan terdiri dari enam faktor yaitu faktor bagi hasil, faktor religiusitas, faktor strategi pemasaran, faktor citra perusahaan, faktor pelayanan nasabah, dan faktor biaya administrasi sebagai faktor yang mempengaruhi nasabah memilih BMT Mandiri Sejahtera.

\section{Interpretasi Faktor}

Berdasarkan analisis faktor yang sudah dilakukan diketahui bahwa drai 17 indikator yang diteliti tersisa 13 indikator yang dapat direduksi menjadi enam faktor:

1. Faktor Bagi hasil
Faktor bagi hasil merupakan faktor yang dipertimbangkan oleh konsumen ketika memilih BMT Mandiri Sejahtera. Bagi hasil yang bersaing dengan BMT maupun Bank lain menjadikan nasabah tidak ragu dalam memilih BMT Mandiri Sejahtera.

Berdasarkan fakta di lapangan, BMT Mandiri Sejahtera, BMT berupaya untuk menetapkan rate bagi hasil yang bersaing dengan lembaga keuangan lain. Dengan menetapkan rate bagi hasil untuk simpanan $0,3 \%-0,6 \%$. Untuk produk pembiayaan $18-20 \%$ per tahun.

2. Faktor Religiusitas

Faktor keimanan (religiusitas) merupakan faktor yang paling dipertimbangkan oleh konsumen ketika memilih BMT Mandiri Sejahtera, hal ini dapat dilihat dari nilai loading rotasi faktor tertinggi yaitu 0,880 . Sebagai pribadi muslim dituntut untuk selalu menghindari aktivitas-aktivitas yang dilarang oleh Allah SWT. Salah satunya yaitu menghindari transaksi riba.

Berdasarkan fakta di lapangan, sebagian besar nasabah BMT Mandiri Sejahtera sudah teredukasi tentang haramnya riba. Tidak hanya sebatas pemikiran namun diimplementasikan juga dalam memilih lembaga keuangan yang bersifat non-ribawi. Sejak pertama berdiri, BMT Mandiri Sejahtera bertahap mengenalkan ke 
masyarakat sekitar bahwa terdapat lembaga kevangan islami yang terbebas dari riba, sehingga masyarakat tidak perlu lagi menabungkan dananya kepada bank konvensional, hal ini direspon positif oleh masyarakat sekitar Karangcangkring Gresik sehingga pertumbuhan BMT Mandiri Sejahtera berkembang pesat dan sekarang telah memiliki 16 cabang.

3. Faktor Citra Perusahaan

Citra perusahaan dalam penelitian ini adalah citra BMT Mandiri Sejahtera yang merupakan salah satu faktor yang dipertimbangkan oleh nasabah BMT Mandiri Sejahtera. Citra BMT Mandiri Sejahtera merupakan BMT dengan kualitas yang baik karena telah banyak menerima penghargaan.

Setiadi (dalam Sawaji dkk, 2011) mengatakan bahwa konsumen cenderung untuk membentuk citra terhadap merek, toko dan perusahaan pada kesimpulan yang diperoleh dari stimuli pemasaran dan lingkungan. Sutojo (dalam Ardianto: 2011) menambahkan citra baik perusahaan menunjang efektifitas strategi pemasaran produk atau jasa sehingga dapat meminimalkan biaya.

Berdasarkan fakta di lapangan, konsumen memilih menjadi nasabah BMT Mandiri Sejahtera karena citra positif yang dimiliki oleh BMT. BMT Mandiri Sejahtera telah menerima berbagai penghargaan, diantaranya adalah peringkat 2 Lomba Koperasi Berprestasi Tingkat Provinsi Jawa Timur 2014, Juara 1 Koperasi Berprestasi dalam rangka Hari Koperasi ke-66 2013, Juara Harapan 2 KSP/KJKS Berkinerja Baik Skala Provinsi Jawa Timur 2014. Dengan banyaknya penghargaan ini semakin meyakinkan konsumen bahwa BMT Mandiri Sejahtera memiliki citra positif di benak konsumen.

4. Faktor Hadiah Menabung

Faktor hadiah menabung merupakan faktor yang dipertimbangkan oleh nasabah BMT Mandiri Sejahtera. BMT Mandiri Sejahtera dalam setiap tahunya memberikan hadiah kepada nasabah yang aktif dalam bertransaksi, sehingga nasabah lebih termotivasi dalam menabung.

Berdasarkan fakta di lapangan, BMT Mandiri Sejahtera menggeluarkan dana ratusan juta setiap periodenya untuk memberikan hadiah kepada nasabah yang terus meningkatkan saldo tabungan. Dengan adanya hadiah, diharapkan mampu untuk menarik minat dan mempertahankan loyalitas nasabah. Karena selain kepuasan atas kualitas pelayanan yang baik, nasabah juga perlu mendapatkan apresiasi atas kesediaan nasabah untuk menyimpan dananya di BMT Mandiri Sejahtera. 
5. Faktor Strategio Pemasaran

Faktor strategi pemasaran
merupakan faktor yang
dipertimbangkan oleh konsumen
ketika memilih BMT Mandiri Sejahtera.
Pada awal pembentukan BMT
Mandiri Sejahtera hingga
sekarang,BMT Mandiri Sejahtera
menerapkan sistem jemput bola
(dalam perspektif syariah disebut
silaturahmi) yaitu dengan
mendatangi para nasabah yang
ingin menyimpan vang maupun
nasabah yang akan meminjam vang.
Gordon (1994:325) yang
mengatakan aspek penting dalam
kegiatan marketing adalah interaksi
antara penyedia jasa dan konsumen
jasa. Interaksi ini untuk
mempertahankan hubungan
pengaruh atau kekuatan dengan
pengguna jasa guna menerapkan
daya tarik.

Berdasarkan fakta di lapangan, BMT Mandiri Sejahtera mempermudah aktivitas jasa yang dibutuhkan nasabah dengan mengirim setiap harinya staff bagi nasabah pembiayaan sehingga nasabah tidak perlu meninggalkan tokonya untuk membayar iuran pembiayaan. Dengan sistem jemput bola juga BMT Mandiri Sejahtera dapat mengetahui kondisi masyarakat sekitar sehingga bila ada masyarakat yang membutuhkan pinjama uang baik komersil maupun qardhul hasan dapat mudah disalurkan. Karena fungsi BMT tidak hanya berpusat pada dana komersil, namun penyaluran dana Zakat, Infaq, Shodaqoh (ZISWAF) kepada masyarakat yang membutuhkan.

6. Faktor Biaya Administrasi

$\begin{aligned} & \text { Faktor biaya administrasi } \\ & \text { faktor yang }\end{aligned}$
dipertimbangkan oleh konsumen
ketika memilih BMT Mandiri Sejahtera.
Biaya yang terjangkau dapat menarik
minat nasabah untuk menabung
pada BMT BMT Mandiri Sejahtera
kejelasan biaya ini diperlukan agar
nantinya calon nasabah tidak
kecewa apabila ternyata tidak sesuai
ketentuan awal.
Sumarwan mengatakan bahwa perusahaan harus mampu menetapkan harga produk yang dapat terjangkau oleh konsumen yang akan membeli produk tersebut. Sejalan dengan Sumarwan, Lupiyoadi dan Hamdani (2009:72) mengemukakan strategi penentuan harga sangat signifikan dalam pemberian nilai kepada konsumen dan mempengaruhi citra produk, serta keputusan konsumen untuk menggunakan jasa.

$$
\text { Berdasar fakta di }
$$
lapangan, BMT Mandiri Sejahtera menerapkan harga yang terjangkau bagi nasabah yang ingin menabung, yaitu iuran pertama Rp. 10.000 Rupiah dan biaya administrasi untuk 
pembuatan buku tabungan dan rekening online. Meskipun BMT merupakan lembaga keuangan mikro, tetapi pada BMT Mandiri Sejahtera mampu menerapkan SOP seperti pada Bank yaitu terdapat Buku Tabungan dan Rekening Online sehingga lebih memudahkan nasabah dalam bertransaksi.

\section{KESIMPULAN DAN SARAN}

Simpulan yang dapat diambil dari hasil penelitian Faktor yang Mempengaruhi Nasabah Memilih BMT Mandiri Sejahtera Gresik adalah:

1. Faktor yang mempengaruhi keputusan nasabah memilih BMT Mandiri Sejahtera terbentuk sebanyak enam faktor. Faktor yang terbentuk dinamai dengan faktor bagi hasil, faktor religiusitas, faktor citra perusahaan, faktor hadiah menabung, faktor strategi pemasaran, dan faktor biaya administrasi.

2. Indikator dengan nilai loading tertinggi yang didapat dari hasil perhitungan rotasi faktor adalah indikator $X_{1}$ pada faktor religiusitas yaitu mengenai transaksi BMT Mandiri Sejahtera yang terbebas dari riba. Hal ini menunjukkan bahwa setiap indikator dari semua faktor yang terbentuk dari keputusan konsumen secara tidak disadari selalu memperhatikan aspek religiusitas saat memilih BMT Mandiri Sejahtera.
Saran yang dapat diambil dari hasil penelitian Faktor yang Mempengaruhi Nasabah Memilih BMT Mandiri Sejahtera Gresik adalah:

BMT Mandiri Sejahtera dapat memberikan reward (hadiah) bagi karyawanya, sehingga karyawan akan selalu meningkatkan kemampuan pelayanan kepada nasabah, dan juga dapat me-motivasi dalam bekerja di BMT. BMT Mandiri Sejahtera juga dinilai perlu memberikan pemahaman kepada para nasabahnya tentang konsep bagi hasil.

\section{DAFTAR PUSTAKA}

Ardianto, Elvinaro. 2011. Handbook of Public Relations: Pengantar Komperhensif. Bandung : Simbiosa Rekatama Media

Dwipurwani, O, Maiyanti, S. I, Desiani, A, dan Oktarina, S. 2009. Penerapakan Faktor dalam Bentuk Laten yang Mempengaruhi Prestasi Mahasiswa FMIPA Universitas Sriwijaya. Jurnal Penelitian Sains (3A): $1-5$

Gordon, Josep. 1994. Strategi dan Program Manajemen Pemasaran. Jakarta: Erlangga

Kotler, Philip dan Armstrong. 2001. PrinsipPrinsip Pemasaran. Terjemahan Jakarata: Erlangga.

Malhotra, Naresh K. 2010. Riset Pemasaran: Pendekatan Terapan. Jilid 1. Jakarta: PT. Indeks

Sudarsono, Heri. 2008. Bank dan Lembaga Keuangan Syariah Edisi 
Ketiga. Cetakan Pertama.

Yogyakarta: Ekonisia.

Prasetijo, I. 2004. Perilaku Komnnsumen

Andi Offset. Yogyakarta

Ratnasari. 2013. Modul Manajemen

Pemasaran Syariah. Jilid 3.

Surabaya : Departemen Ekonomi

Syariah, Fakultas Ekonomi dan

Bisnis Universitas Airlangga

Sawaji, Jamaluddin, Djabir Hamzah, Idrus

taba. 2011. Pengambilan

Keputusan Pembelian Teh Celup

Sariwangi Oleh Konsumen Rumah

tangga di Kota Medan. Medan:

Pascasarjana Universitas Sumatera

Utara

Simamora, B. 2004. Analisis Multivariat

Pemasaran. Gramedia Pustaka

Utama. Jakarta

Sumarwan, Ujang. 2011 . Perilaku

Konsumen: Teori dan Penerapanya

dalam Pemasaran. Edisi Kedua.

Bogor: Ghalia Indonesia

Solimun. 2003. Structural Equation

Modeling Lisrel dan Amos. Fakultas

MIPA Universitas Brawijaya, Malang 